„Kwartalnik Filmowy” nr 114 (2021)

ISSN: 0452-9502 (Print) ISSN: 2719-2725 (Online)

https://doi.org/10.36744/kf.788

(c) Creative Commons BY-NC-ND 4.0

\title{
Magdalena Podsiadło-Kwiecień
}

Uniwersytet Jagielloński

https://orcid.org/0000-0003-3641-964X

\section{Między daznymi i młodszymi laty - (neo)animistyczne i (neo)pogańskie tropy w kinie polskim}

\author{
Słowa kluczowe: \\ animizm; \\ pogańszczyzna; \\ kino polskie; \\ abiekt
}

\begin{abstract}
Abstrakt
W obrębie nowego animizmu proponuje się podejście do podmiotowości odmienne od zbudowanego na tradycji judeochrześcijańskiej, inną relację między naturą a kulturą, światem ludzkim i nie-ludzkim oraz ożywionym i nieożywionym. Elementy tego nurtu, peryferyjnego w kulturze polskiej, można odnaleźć w filmowych obrazach pogańszczyzny nadających mu status zjawiska wypartego bądź oswojonego przez chrześcijański kontekst. Twórcy współczesnych filmów polskich odwołując się do tej tradycji szukają w niej innego spojrzenia na świat niż hierarchiczne, dualistyczne, oparte na modelu antropocentrycznym. Dzieła te łączy z ową tradycją egalitarny stosunek do świata zwierzęcego, szacunek do sprawstwa roślin, wiara w obecność duchów wykraczająca poza kontekst chrześcijański, wrażliwość na środowisko czy odniesienie do kultur pierwotnych. Jednocześnie autorzy tych dzieł dokonują jej rewaloryzacji, traktując ją jak „perspektywę ratunkową” w obliczu współczesnego kryzysu cywilizacyjnego.
\end{abstract}


Katarzyna Klimkiewicz - twórczyni znana z dzieł krytycznych, które cechuje wrażliwość na nierówności, napięcia kulturowe czy wykluczenia - w jednym z wywiadów zapowiadała realizację filmu odnoszącego się do okresu wczesnochrześcijańskiego. Noszę się też z pomysłem na scenariusz o pewnym zapomnianym buntowniku, Miecławie, znanym też jako Masław. Żył w XI w. Do jego zamku w Płocku ściagali buntownicy, którzy przeciwstawiali się nowym porządkom po Chrzcie Polski. Miectaw wzniecit powstanie pogańskie. Pozostała po nim legenda dzikiego i krwawego pogańskiego bojownika. Ja widze w nim też nonkonformiste, w jakimś sensie byt alterglobalista, który w swoim zamku stworzył coś jakby skłot dla wszystkich buntowników, którzy kontestowali korporacje - jaka w tamtych czasach był Kościót Katolicki. Widzę w nim takiego Ostatniego Mohikanina, który próbuje ocalić swoja słowiańska tożsamość przed kolonizacja. Pracuję nad kluczem do opowiedzenia tej historii ${ }^{1}$. Niestety nigdy nie doszło do sfinalizowania tego projektu, który zapowiadał odwołanie do problematycznej w polskiej kulturze tradycji pogańskiej i jej aktualizację, a przede wszystkim nietypowe rozłożenie sympatii ${ }^{2}$ wobec bohaterów tego wczesnochrześcijańskiego dramatu.

Wydawać by się mogło, że plany snute przez Klimkiewicz znacząco różnią się od jej ostatniego projektu, czyli zrealizowanego wspólnie z Domingą Sotomayor Castillo krótkometrażowego filmu Wyspa (2013). Akcja rozgrywa się na chilijskiej wyspie, dokąd przybywa rodzina mężczyzny, który - jak się domyślamy zginął w pierwszej scenie filmu. Niewiedzącym o wypadku członkom rodziny, oczekującym na jego przybycie, czas wypełniają posiłki, eksploracja wyspy i rozmowy o przeszłości. Niecodzienny sposób realizacji dzieła Klimkiewicz i Castillo polega na tym, że widz przyjmuje w nim perspektywę wyspy. Spojrzenie kamery jest upodmiotowione, lecz oderwane od antropocentrycznego źródła i przekazane wyspie, dzięki czemu przyjmuje ona status osobowy. Gdy w ostatniej scenie filmu widzimy z oddalenia dom, w którym zgromadzeni przybysze krzątają się w kręgu światła, utożsamiamy się z owym zsubiektywizowanym spojrzeniem należącym do wyspy bądź - ewentualnie - do zmarłego bohatera. W obu przypadkach - niezależnie od przyjętej interpretacji - nie-ludzkie byty (wyspa lub duch zmarłego) zyskują podmiotowość, co koresponduje z animistyczną wizją świata.

Zatem zarówno projekt dotyczący czasów przedchrześcijańskich, jak i współczesna opowieść o rodzinnym zgromadzeniu (ujęta jednak w ramy nieantropocentryczne) starają się wyjść poza greko-rzymską i judeochrześcijańską tradycję. Jak sugeruje Anna Filipowicz, alternatywy dla tego silnie zhierarchizowanego i wykluczającego porządku dostarczają bardziej zdemokratyzowane wizje świata, wykraczające poza podziały dualistyczne charakterystyczne dla zachodniej cywilizacji. Taką furtkę - według autorki - stanowi nowy animizm, proponujący postsekularne odczytywanie pradawnych wzorców myślenia o świecie, przechowywanych przez wiedze tubylcze i autochtoniczne praktyki postrzegania rzeczywistości. Z animistycznym podejściem wią̇a się bowiem alternatywne wobec zachodnich sposoby ujmowania podmiotowości, relacji między natura i kultura, międzygatunkowych zwiąków oraz miejsca człowieka pośród innych bytów - ożywionych i nieożywionych ${ }^{3}$.

Odległe, wydawałoby się, projekty Klimkiewicz są sobie zatem bliskie pierwszy odnosi się do zmarginalizowanej przez chrześcijaństwo pogańszczyzny, ujmowanej z perspektywy kultury oficjalnej jako wyparta inność z wpisanym w nią animistycznym subtekstem; natomiast drugi proponuje alternatywną wobec tradycji judeochrześcijańskiej nieantropocentryczną animistyczną wizję świata. 
Oba światopoglądy łączy w kulturze polskiej peryferyjny status, bardziej lub mniej krytyczny stosunek wobec dominujących wzorców oraz wspólne odniesienia do animizmu, spirytyzmu czy szamanizmu. Podzielają one także spojrzenie na relacje z nie-ludzkim światem oparte na ciągłości dalekiej od dualistycznych podziałów na umysł/ciało, ludzkie/zwierzęce, ożywione/nieożywione.

Problematyczny i „źle obecny” status wspomnianych tradycji ma swoje tożsamościowe konsekwencje. Według Marii Janion wyparcie przedchrześcijańskiej Słowiańszczyzny jest przyczyną dojmującego poczucia narodowej niższości z racji pogardy wobec własnych korzeni, a jednocześnie podstawą mesjanistycznej megalomanii i lekceważącego stosunku do Wschodu. Ta tożsamościowa pułapka wymaga zatem alternatywy w postaci odmiennego polskiego imaginarium ${ }^{4}$, które wbrew oczekiwaniom - nie wykształciło się w kulturze po transformacji ustrojowej. Tropem tego braku podąża Anna Filipowicz ${ }^{5}$, już w tytule swojego artykułu zwracając uwagę, że warto zaktualizować przeszłość ${ }^{6}$. Według autorki postsekularne i postzależnościowe spojrzenie - skorelowane z nowym animizmem - pozwala nie tylko przychylniej spojrzeć na pradawną kulturę tubylczą i poddać ją rehabilitacji, ale i poszukać w niej recepty na współczesny kryzys cywilizacyjny, czyli potraktować ją jak rodzimą „perspektywę ratunkową”. W innym miejscu autorka definiuje ją jako oczywiste remedium na pooświeceniowy rozziew między człowiekiem a natura, na zerwanie bliskości z przyrodniczym środowiskiem. W dobie nadchodzacego kryzysu ekologicznego i wią̇acych się z nim negacjonistycznych reakcji, spowodowanych również kryzysem racjonalnego paradygmatu, jej wartość wydaje się nieoceniona ${ }^{7}$.

Dwa projekty Klimkiewicz - pierwszy dotyczący przedchrześcijańskej Słowiańszczyzny i kolejny czerpiący ze współczesnych źródeł animistycznych - wyznaczają ramy ewolucji tego światopoglądu. Sięga ona od średniowiecznego zrepresjonowania, przez ostrożną fascynację romantyków tą niechcianą tradycją (włącznie z nie zawsze udaną próbą jej unarodowienia), po jej współczesną adaptację. Ze względu na wczesnochrześcijańską marginalizację tego dziedzictwa funkcjonowało ono jako wyparte bądź budziło grozę, by obecnie doczekać się częściowej rewaloryzacji. Maria Janion ujęła wyrugowanie pogańskiej tradycji właśnie w kategoriach wyparcia, co skłoniło ją do wskazania abiektalnego charakteru wyobrażeń ludowych rozpostartych między tym, co ludzkie i animalne, żywe i umarłe, odrażające i fascynujące, wykluczane i przynależne ${ }^{8}$. Podobną funkcję pełniła sama pogańszczyzna, zarówno jako źródło tożsamości, jak i jej zaprzeczone dziedzictwo.

Wyjście poza dualistyczną wizję świata pozwoliło na tożsamościowe zmącenie, przerwanie granic między separowanymi dotąd kategoriami i bardziej afirmatywne ujęcie tradycji dotychczas negowanej. (Neo)animistyczne spojrzenie na rzeczywistość szerzej zagościło w ostatniej dekadzie w polskim kinie, co jest być może sygnałem poszukiwań wspomnianej i postulowanej perspektywy ratunkowej. Filmy takie jak Pokot (2017) i Szarlatan (2020) Agnieszki Holland, Wieża. Jasny dzień (2017) Jagody Szelc, wspomniana Wyspa Katarzyny Klimkiewicz, Baba Wanga (2016) Aleksandry Niemczyk, Walser (2015) Zbigniewa Libery czy Body/Ciało (2015) i Śniegu już nigdy nie będzie (2020) Małgorzaty Szumowskiej, na różne sposoby wpisują się w perspektywę nowego animizmu bądź wprost sięgają do neopogańskich tradycji. 


\section{Poza zasadą chrześcijaństwa}

Nim jednak pogańska tradycja doczekała się reinterpretacji, została poddana daleko idącej marginalizacji, głównie ze względu na jej charakter antychrześcijański. Deficyt i nieprawomyślność pogańszczyzny stały się przedmiotem wypowiedzi Andrzeja Sapkowskiego w jego znanym eseju Piróg albo Nie ma złota w Szarych Górach ${ }^{9}$, w którym ubolewa nad zaprzepaszczeniem przedchrześcijańskiego dziedzictwa. Przytaczając opowieść o Mieszku, który wybijał zęby za łamanie postu, Sapkowski wskazuje, że cała prasłowiańska mitologia wyleciała z naszej kultury i z naszych marzeń niby owe zęby, wyplute z krwia. (...) W polskiej, archetypicznej krainie marzeń nie było wszak Dobra i Zła, było tam wyłacznie Zło, na szczęście Mieszko przyjąt chrzest i wybit Złu zęby, $i$ od tej pory jest już tylko dobro $i$ Ład, i Przedmurze, i co nam tam diabet Boruta, woda święcona go, skurwysyna ${ }^{10}$. Głos Sapkowskiego jest bliski tezom XIX-wiecznego etnografa i propagatora Słowiańszczyzny Zoriana Dołęgi-Chodakowskiego, którego radykalne poglady na destruktywna role chrześcijaństwa dla polskiej kultury wyptywały z przekonania o zbyt wczesnym chrzcie naszych ojców ${ }^{11}$. Tymczasem $\mathrm{w}$ dominującej narracji, według której przyjęcie chrześcijaństwa otworzyło Słowian na cywilizowany świat, pozachrześcijański charakter pogańszczyzny był waloryzowany negatywnie.

Temat ów podjął zrealizowany w 1974 r. film Jana Rybkowskiego zatytułowany Gniazdo, w którym - w ramach obowiązującej wówczas polityki historycznej - zostały przedstawione początki chrystianizacji. Poszukiwanie tematów historycznych o wymowie triumfalistycznej skierowało twórców filmowych poza wiek XX. Widowiska takie jak Kopernik (1972) i Kazimierz Wielki (1975) Ewy i Czesława Petelskich czy właśnie Gniazdo pozwalały na demonstrację siły trudniejszą do zaprezentowania w narracjach dotyczących II wojny światowej dominujących w kinie historycznym. Jolanta Lemann-Zajiček, charakteryzując pomarcowy okres twórczości Rybkowskiego, wskazuje, że przypadły na niego filmy, w których demonstracyjnie podkreślał lojalność wobec władzy i poszukiwał tematów "bezpiecznych"12. Do filmów tych autorka zalicza wspomniane Gniazdo, korespondujące z retoryką sukcesu Edwarda Gierka. Istotnie film ma wydźwięk państwotwórczy, zgodny z linią ówczesnej władzy, przez wsparcie rządów silnej ręki (w jednej ze scen główny bohater wykrzykuje: Jedna myśl, jedna wiara, jedna ręka!), idei rdzenności ziem polskich między Wisłą a Odrą łączności ze wspólnotą słowiańską (przyjęcie chrztu przez Mieszka I z rąk Czechów) oraz zachowanie niezależności od świata zachodniego (relacje z Sasami). W stosunku do pogańszczyzny film nie pozostawia złudzeń: tradycję tę znamionuje słabość i bierność, i jako taka jest ona bezużyteczna.

Mimo że było to dzieło z wyraźną intencją popularyzatorsko-dydaktyczną, zostało zrealizowane z pietyzmem i zawierało najnowsze ustalenia historyków ${ }^{13}$. Dlatego film cechuje pewna niejednoznaczność, gdy celebrze silnej władzy towarzyszy poczucie straty i pociągająca wizja pluralistycznej, wielobarwnej pogańszczyzny, z różnorodnymi bóstwami, gdzie każde z plemion rządzi się swoimi prawami. Mieszkańcy tych ziem są cząstką wszechświata, tworzą wspólnotę ze zmarłymi wędrującymi po bagnach czy dzikimi zwierzętami. Zioła z kadzi wiedźmy pomagają Mieszkowi wyzdrowieć i wygrać decydującą bitwę, a jej wskazówki i mediacja z nieżyjącym ojcem doprowadzają do zgody między światem żywych i zmarłymi, których status ontyczny niewiele się różni. Przyjęcie wiary chrześci- 
jańskiej jest więc traktowane instrumentalnie, jak parasol ochronny przed ewentualnym skolonizowaniem przez kraje ościenne i prowadzi do tragedii Słowiańszczyzny, która musi się wyrzec tożsamości, by przetrwać. Tym samym Mieszko, odrzucając swoje dziedzictwo i kwestionując przedchrześcijański porządek, jednocześnie z żalem go żegna.

Wątpliwości tych nie podzielał już Jerzy Hoffman, który odniósł się do tego okresu za sprawą adaptacji Starej baśni (2003), przedstawiając w niej okrutne i krwawe rządy Popiela oraz ich upadek. Ekranizację Hoffmana łączy z Gniazdem m.in.: dydaktyczny charakter filmu, przedstawienie czasów przedchrześcijańskich, pochwała silnej władzy w przeciwieństwie do słabego ustroju wiecowego. Mimo tych zbieżności film Hoffmana ustępuje filmowi Rybkowskiego nie tylko pod względem artystycznym, ale i pod względem skomplikowania w ukazaniu dziejów. O ile Gniazdo poddaje refleksji bilans zysków i strat przyjęcia chrześcijaństwa, o tyle Stara baśń Hoffmana zupełnie pomija ten wątek. W epilogu triumfujący głos narratora informuje widzów o dalszych losach książąt, dochodząc aż do Mieszka I, który wyciąt święte dęby, obalit stare bogi, wprowadził do kraju Polan wiarę w Jezu Chrysta. Tym samym walki o władzę między słowiańskimi książętami oraz wiecowe awanturnictwo są jedynie warcholskimi wybrykami poprzedzającymi osiągnięcie dojrzałości politycznej za sprawą chrystianizacji. Hoffman podąża tu za Kraszewskim, dla którego wraz z chrześcijaństwem łacińskim dzieje Polski się rozjaśniaja - naród wchodzi na właściwa drogę ${ }^{14}$. Pluralistyczna wizja świata zostaje zastąpiona chrześcijańskim monologiem i ideą monokulturowości.

Mimo odświeżającego formalnie spojrzenia na chrystianizację w filmie Bartosza Konopki Krew boga (2018) jego twórcom nie udało się wyjść poza tradycyjne ideowo ramy. Historia dwóch misjonarzy - Willibrorda i Bezimiennego - próbujących za sprawą chrztu uchronić pogan przed śmiercią z rąk nadciągającego króla, prowadzi ostatecznie do konstatacji, że przemoc jest ślepą uliczką w przeciwieństwie do reprezentowanego przez Bezimiennego miłosierdzia. Poganie tracą jednak $\mathrm{w}$ opowieści Konopki podmiotowość, stając się jedynie przedmiotem ideowego wewnątrzchrześcijańskiego sporu, który wysuwa się na plan pierwszy. Ich wierzenia są potraktowane jak baśniowa, prymitywna, wstępna wersja religii monoteistycznej, nad której błędami, a także niekwestionowaną duchową potęgą pochyla się Konopka. Podobnie jak w poprzednio wspomnianych filmach, pogańszczyzna zostaje przezwyciężona i zastąpiona przez nowy system religijny, nie stanowiąc dla niego ani konkurencji, ani alternatywy.

\section{Sa w puszczach litewskich rzeczy $i$ sprawy, o których nie śnito się filozofom ${ }^{15}$, czyli romantyczne fascynacje}

Odrzucenie pogańszczyzny zostało częściowo przezwyciężone za sprawą działalności przywoływanego już Zoriana Dołęgi-Chodakowskiego, który przywrócił tę tradycję epoce romantycznej. Lęk i fascynacja nie tylko pogańską, ale i animistyczną wizją świata zawarte w utworach romantyków korespondowały z problematycznym, peryferyjnym statusem pogańszczyzny, wspartym przez jej wschodni i plebejski rodowód. Według Chodakowskiego, który śladów przedchrześcijańskiej Słowiańszczyzny szukał na wschodnim pograniczu, region 
ten zachował pozostałości dawnego autochtonicznego myślenia o relacjach człowieka i natury, przenikaniu się ludzkich i nie-ludzkich światów, podmiotowym statusie zwierzęcych i roślinnych bytów ${ }^{16}$. Romantycznym wyrazem fascynacji tą wizją powiązanym ze wschodnim pograniczem jest opowiadanie Prospera Mérimée Lokis, przedstawiające podróż na Litwę niemieckiego pastora Wittembacha w celu poznania folkloru i języka żmudzkiego. Adaptacja tekstu zrealizowana przez Janusza Majewskiego w 1970 r. została uzupełniona o rodzime odniesienia literackie i nawiązania do lokalnego folkloru, dzięki czemu przywołała animistyczne tradycje obecne w polskim romantyzmie oraz niepokojącą peryferyjność pogańszczyzny. Jak relacjonuje reżyser: Literacka legenda głosi, że Mérimée opart swoje opowiadanie na historii przekazanej mu w Paryżu przez jakaśs Polkę. Przypomnijmy, że było to w latach 60. XIX w., kiedy to kolejna popowstaniowa fala emigrantów polskich zalała nie tylko bruki, ale i salony paryskie, stąd opowiadanie to wydaje się jakaśs salonowa wersja mickiewiczowskich motywów romantycznych jak "Świtezianka” czy "Dziady". Ten trop postanowiłem rozwinać, wpisując w film więcej polskich klimatów literackich epoki, trochę autentycznego litewskiego folkloru i troche prawdopodobnych realiów obyczajowych ze stylu życia kresowej arystokracji $i^{17}$.

W historii hrabiego, który broni się przed swoją niedźwiedzią natura, reżyser poczynił uzupełnienia adaptacyjne, pozwalające silniej zaakcentować pogański charakter opowieści oraz animistyczną i podmiotową wizję nie-ludzkiego świata. Twórca rozwinął motyw matecznika, gdzie przebywają zwierzęta poza ludzką jurysdykcją. Tam żyja zwierzęta w ustroju republikańskim... może pod rzadem konstytucyjnym, nie umiałbym powiedzieć, pod którym z dwojga ${ }^{18}$ - peroruje nowelowy hrabia. Tymczasem Mickiewiczowski matecznik - według Anny Barcz - stanowi w epoce romantyzmu wyjątek na tle innych przedstawień przyrody, ponieważ jest próbą ukazania jej jako niezależnego od ludzi bytu ${ }^{19}$. Tym samym jest to miejsce, które nie da się oswoić, z zamieszkujacymi go wówczas, a dziś wymartymi turami, czy obecnie chronionymi z uwagi na niewielka liczebność - żubrami i niedźwiedziami20. Majewski uzupełnia wątek matecznika o scenę przemarszu żubrów, czego świadkami są hrabia i profesor. Przypatrują się oni z ukrycia nieświadomym ich obecności zwierzętom, podporządkowując ich obraz ludzkiej perspektywie. To antropocentryczne spojrzenie zostanie jednak przełamane w dalszej części filmu, gdy Wittembach śni koszmar o żubrze: zwierzę zyskuje w nim autonomię, bezpardonowo patrząc widzowi i śniącemu prosto w oczy.

Drugą znaczącą modyfikacją adaptacyjną są zmiany w odniesieniu do twórczości Mickiewicza. Cytowaną przez Mérimée balladę Trzech Budrysów, opowiadającą o trzech mężach, którzy z wypraw wojennych przywieźli żony - Laszki, reżyser zmienia na Świteziankę, czyli opowieść odwołującą się do folkloru i przedchrześcijańskich zabobonów o nimfie wodnej. Wprowadza także motyw teatru nieobecny w pierwowzorze - w którym hrabia odgrywa fragment Mickiewiczowskich Dziadów, dzieląc się z Wittembachem zamiarem ich wystawienia. Istotny jest jednak wybór przez twórcę fragmentu dramatu, który przedstawia chór nocnych ptaków: Szarpajmy jadło na sztuki; / A kiedy jadła nie stanie, / Szarpajmy ciało na sztuki, / Niechaj nagie świeca kości!21 Anna Filipowicz, śledząc animistyczną spuściznę w tekstach romantyków, pisze: Animistyczny rodowód zdaja się po części mieć choćby znane z II części "Dziadów" duchy zmartych chłopów, które przybywaja na obrzęd w skrzydlatej postaci (jako Sowa i Kruk) bądź w ramach pokuty cierpia niedole rzeczywistych ptaków (zwiazany z jesienno-zimowa pora roku głód i chłód). Tym bardziej że zebrana 
w kaplicy wiejska gromada ofiarowuje swym gościom jedzony zwykle przez dzikie zwierzęta pokarm, rozpoznając w nich kondycje wyraźnie heterogeniczne - przemieszczajace się nie tylko między życiem a śmiercia, lecz także między różnopostaciowymi klasami stworzeńn ${ }^{22}$. Tym samym Majewski w swojej adaptacji podkreśla "gatunkową przechodniość", która ostatecznie doprowadzi nie tylko do zezwierzęcenia ludzi (jak dzieje się to w przypadku hrabiego Szemiota oraz zgwałconej przez niedźwiedzia hrabiny), ale też do upodmiotowienia zwierząt. W końcowej scenie opuszczający Żmudź profesor Wittembach z okna pociągu widzi rozłożony na peronie pokot, nad którym zaczyna odmawiać Wieczny odpoczynek. Skoro otaczające nas byty moga zmieniać swoja zewnętrzna formę cielesna, w jakiej manifestuja się innym, (...) to (...) podmiot nigdy nie ma pewności, z kim ma do czynienia ${ }^{23}$. Przystanie na gatunkową przechodniość sprawia, że potencjalnie każde zwierzę może być zamieszkiwane przez duszę, nad którą należy odmówić modlitwę.

Profesor Wittembach, reprezentujący oświeceniowy racjonalizm, w jednej ze scen opowiada o piciu końskiej krwi, które uratowało mu życie. Bohater reaguje na to wspomnienie abiektalnym wstrętem, w przeciwieństwie do hrabiego uwiedzionego taką wizją. Ten ostatni sam jednak stanowi ruchomą granicę między ludzkim i zwierzęcym, czyli - jak pisze definiująca abiekt Kristeva - tym, co mu zagraża, i co jak się zdaje nadchodzi z zewnatrz lub rozsadza od wewnatrz, rzucone obok tego, co dopuszczalne, tolerowane, możliwe do pomyślenia ${ }^{24}$. Ostatecznie porządek zostanie przywrócony, a fascynująca pogańska obcość okiełznana dzięki śmierci bądź ucieczce hrabiego i racjonalizującym wyjaśnieniom lekarza rodzinnego, który wyklucza istnienie zwierzęcej natury Szemiota.

Kolejny „pogański” film Majewskiego - Epitafium dla Barbary Radziwiłłówny (1982) - nie igra już tak odważnie z nie-ludzkim światem. Bez ironicznego cudzysłowu utożsamia to co pogańskie z obcością etniczną, kobiecością oraz śmiercia, dążąc do ich przezwyciężenia. Dzieło Majewskiego pod względem konstrukcji przypomina powieść Williama Faulknera Kiedy umieram. Król wraz z dworem wiezie zwłoki Barbary na Litwę i jednocześnie - wraz z dwoma podwładnymi - wspomina królową. Reminiscencje, rozkładające się zwłoki i walka z żywiołami (pożar czy tragiczna w skutkach przeprawa przez rzekę) są analogiczne do powieści amerykańskiego pisarza - z jednym jednak wyjątkiem - zwłoki Radziwiłłówny milczą. W solilokwium Faulknera zmarła przemawiała, tymczasem postać Barbary została przemieniona w ulegającego rozkładowi trupa, poddanego po drodze pogańskim obrządkom - znak wypartego, wy-miot, gdzie odpad $i$ trup wskazują (...) to, co permanentnie odsuwam, żeby $\dot{z} y c^{25}$. O ile dramat Barbara Radziwiłłówna Alojzego Felińskiego z $1817 \mathrm{r}$. uczynił z bohaterki symbol narodowy, upokorzona matkę-Polskę, ofiare zbrodni rozbiorów $w^{26}$, dając podstawy pod mit mesjański, o tyle zdegradowany trup Barbary w filmie Majewskiego służy wyegzorcyzmowaniu tego, co litewskie, pogańskie i kobiece. Wraz z jej śmiercią zostaje przywrócona jedność etniczna, dynastyczna, chrześcijańska i tradycyjny porządek płci. Ostatnie sceny monumentalizują Zygmunta Augusta, prezentując go jako silnego władcę, który stanie na czele państwa po rządach królowej Bony. Barbara zaś przemieniona pośmiertnie w łagodną nimfę wodną zjawia się przed bohaterem z odsłoniętą powabnie piersią. Jej pogańskość została oswojona, a co za tym idzie, pozbawiona magicznej siły litewskiej wiedźmy z Lokisa, która rozmawiała z wężami i chodziła po bagnie jak Chrystus po wodzie, czy czarownicy z Gniazda, której moc wpłynęła na losy państwa. 


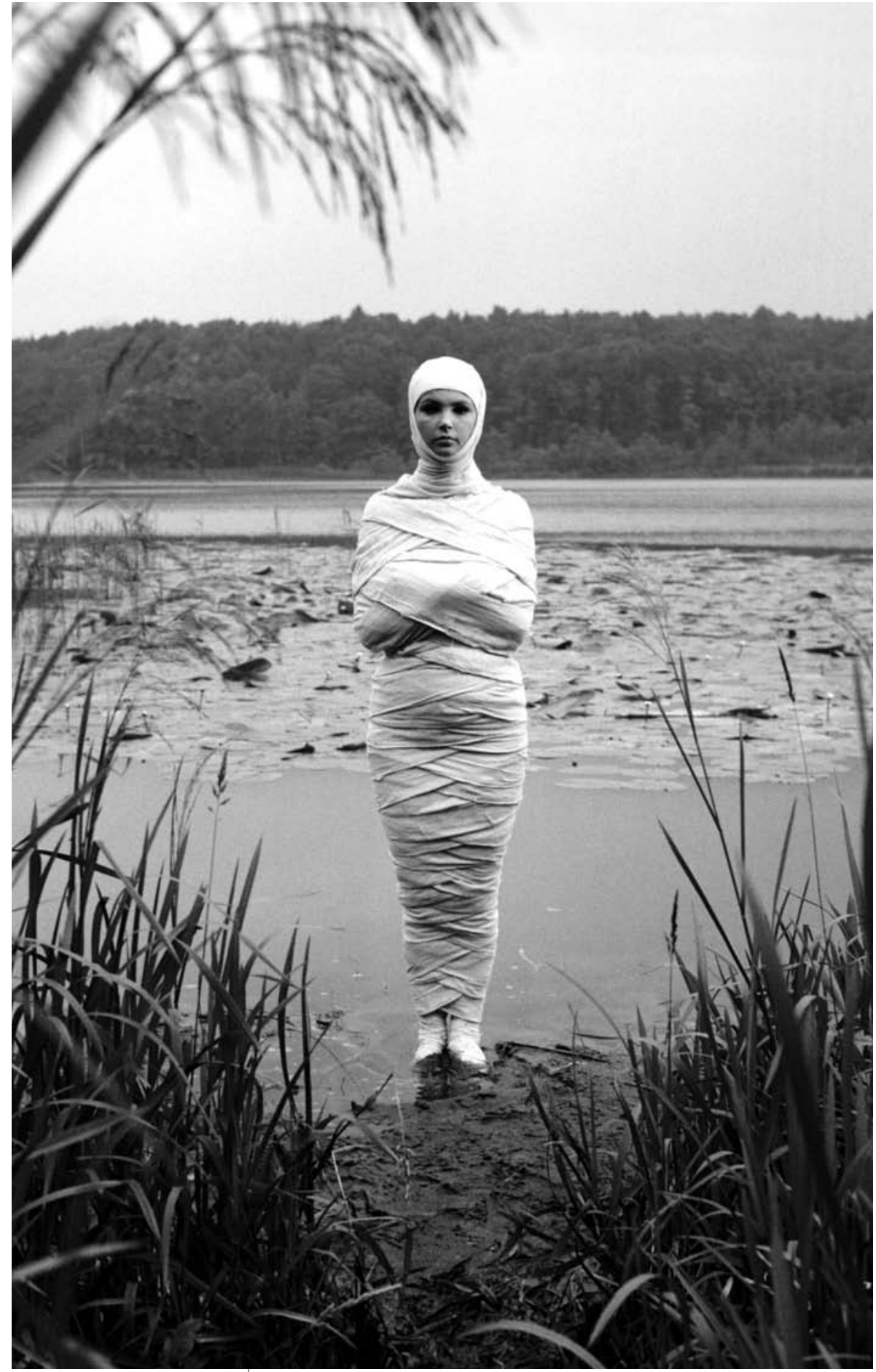

Epitafium dla Barbary Radziwiłtówny, reż. Lech Majewski (1982) 


\section{Myśl nieoswojona}

O ile filmy Majewskiego wystarczająco ujarzmiały nieoswajalne, o tyle strategia ta zawiodła w odniesieniu do zrealizowanych przez Piotra Szulkina filmów krótkometrażowych, co wpłynęło na ich recepcję. Twórca, inspirując się polskim folklorem, w oryginalny sposób połączył go z językiem awangardy. W trzech filmach - Narodziny (1974), Dziewica z ciortem (1975), Oczy uroczne (1976) - reżyser zawarł niepokojący obraz kultury ludowej, daleki od stereotypu łagodnej i sielskiej Słowiańszczyzny. O ile dwa pierwsze filmy za sprawą wpisania w ramy moralitetu stają się swego rodzaju przypowieścia, o tyle Oczy uroczne cechuje romantyczna stylistyka okrucieństwa i gwattu ${ }^{27}$ daleka od umoralniających pouczeń. Film opowiada historię Pana, którego śmiercionośny wzrok skazuje go na żywot piwniczny, a ostatecznie doprowadza do samooślepienia. Obraz zawiera upiorne sceny z wyłupionymi pulsującymi gałkami ocznymi, po których przechadzają się muchy. Uczucie wstrętu budzi nie tylko ten makabryczny lejtmotyw, ale także sam status postaci, przypominającej żywego trupa pogrzebanego w zamku-grobowcu. Dreszcz budzi także młoda żona, z której stopniowo uchodzi życie, samooślepienie, a także nowo narodzone dziecko, które prawdopodobnie zostało zarażone śmiercionośną mocą. Demoniczność nie podlega jednak w filmie chrześcijańskiej kontroli, stając się niepokojącą i immanentną cechą przedstawionej rzeczywistości.

Marcin Maron, podkreślając związki Oczu urocznych z ekspresjonizmem niemieckim, wskazuje na zawartą w filmie aurę niesamowitości, odrealniony charakter scenerii, stylistykę wizualną bliską filmowi Nosferatu - symfonia grozy (Nosferatu, eine Symphonie des Grauens, 1922) F. W. Murnaua. Jednocześnie autor utrzymuje, że to właśnie ludowość romantyczna i balladowość uruchomiły w filmie inspiracje ekspresjonistyczne. Mimo wskazywanych przez autora związków z Mickiewiczem obraz Szulkina bliższy jest jednak Królowi olch czy Piaskunowi, ciążąc - także w interpretacji Marona - w stronę niemieckiego romantyzmu i ekspresjonizmu. Cały świat przedstawiony w "Oczach urocznych" jest przesycony owa irracjonalna siła witalna (...) niwelujaca granice pomiędzy tym, co ożywione i nieożywione, rodzaca i niszczaca zarazem ${ }^{28}$ - pisze autor. Maria Janion, wskazując na obecność frenezji romantycznej, podkreślała, że jej źródeł szukano właśnie we wpływach niemieckich. Szczególnie niepokojące wydawały się obrazy śmierci w postaci freudowskiego Niesamowitego, nieoswajalne przez kody narodowe lub religijne ${ }^{29}$, które wydobywa[ły] na powierzchnię coś obcego i swojskiego zarazem ${ }^{30}$.

Filmy Szulkina spotkały się z gwałtowną reakcją środowisk stojących na straży jednoznaczności dyskursu narodowego i ludowego. Twórca relacjonuje, że po ich realizacji stał się przedmiotem antysemickiego ataku ze strony między innymi „Ekranu”. W jednym z artykułów autor wymieniał expressis verbis realizatorów podejrzanych o "nieprawe" pochodzenie ${ }^{31}$, nazywając ich nietutejszymi tubylcami. Jak wspomina zaliczony do tego grona twórca: Zarzucano mi, że zniekształciłem obraz kultury polskiej32, że bezczeszczę i zafałszowuję obraz kultury narodowej, jako nietutejszy, „innostroniec". (...) Ten tekst „Nietutejsi tubylcy”, który wymieniat po imieniu Falka, Agnieszkę Holland, mnie i pewnie kogoś jeszcze, zwracał uwage, że stanowimy desant "piątej kolumny" na Polskę. Powiedziałem sobie: Nigdy w życiu nie zrobię filmu o polskiej kulturze ludowej3. 

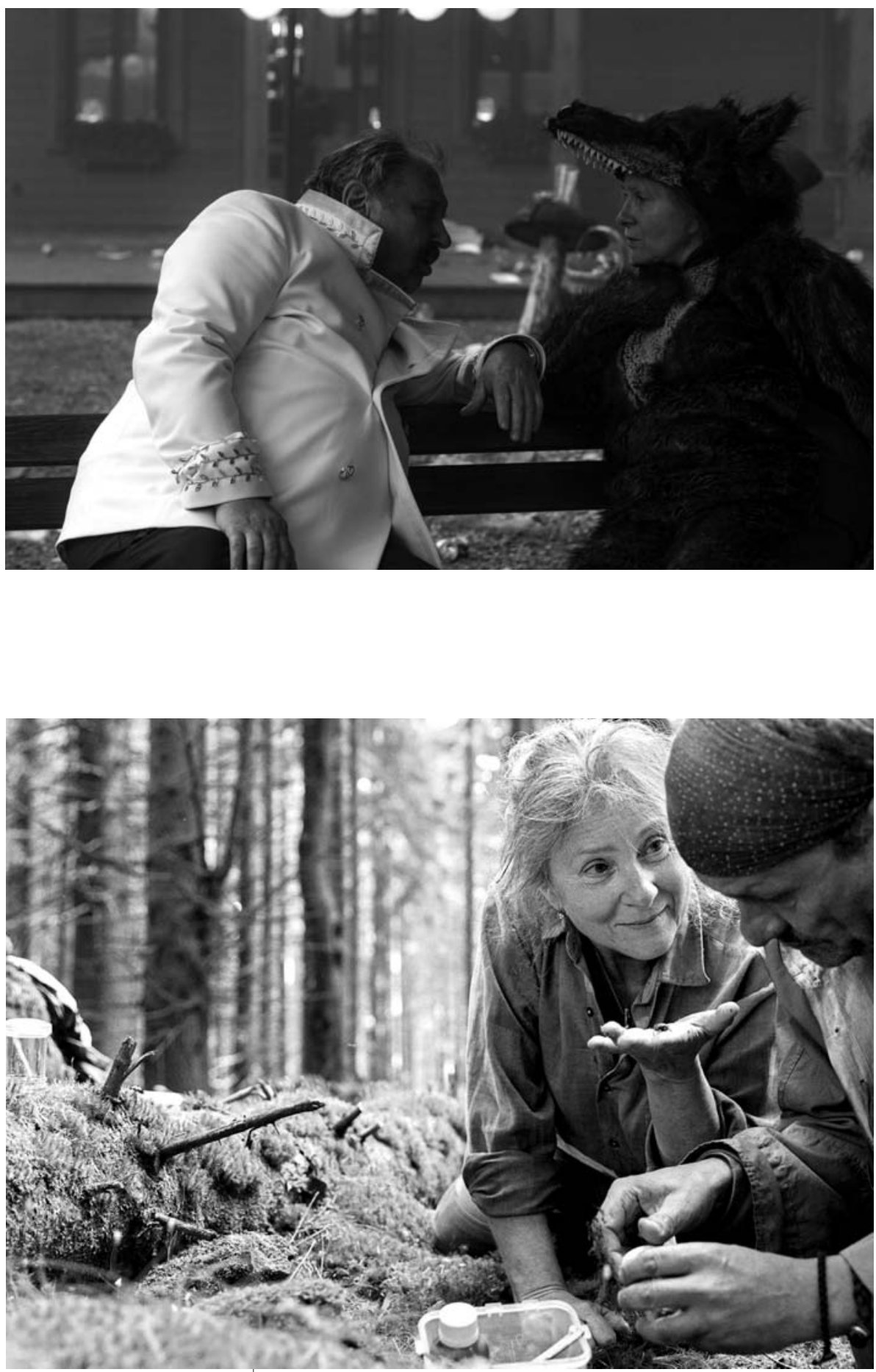

Pokot, reż. Agnieszka Holland (2017) 
„Nietutejsza tubylczość” stanowi w gruncie rzeczy doskonałą definicję abiektalnej niejasności, równoczesnej przynależności do kultury polskiej i zaniepokojenia treściami, które wydają się zagrażać jej spójności. Ich niewystarczające oswojenie wewnątrz świata przedstawionego zaowocowało dyscyplinującym artykułem przepełnionym abiektalnym wstrętem do obcości, który na powrót oddzielił podmiot narodowy od wy-miotu.

\section{(Nowy) animizm wobec współczesności}

Tymczasem w najnowszych filmach czerpiących z (neo)pogańszczyzny i (nowego) animizmu stosunek do inności ma daleko bardziej afirmatywny charakter, poczynając od spojrzenia na odmienność etniczną (Śniegu już nigdy nie będzie, Baba Wanga), gatunkową (Pokot), seksualną (Szarlatan) czy ontologiczną (Wyspa, Body/Ciało). To, co budziło dotąd lęk i fascynację, prowokując do wyznaczenia jasnych granic i stygmatyzacji, współcześnie jawi się - by wrócić do tezy Filipowicz jako perspektywa ratunkowa, zachęcająca do akceptacji różnorodności, a także ponownego zdefiniowania statusu osoby, przeformułowania relacji między światem ludzkim i nie-ludzkim, ożywionym i nie-ożywionym czy duchem i materią. Według Ewy Domańskiej nowy animizm może stać się podstawą nie tylko budowy przyszłych wizji świata, lecz także ważnym sposobem widzenia świata i bycia człowiekiem w świecie kultury, wspomagającym ko-egzystencję i zrównoważony rozwój34.

Podstawowym aspektem, na który zwracają uwagę przedstawiciele nowego animizmu, jest odejście od modernistycznej dwubiegunowej wizji rzeczywistości. Nurit Bird-David, izraelska badaczka, która przyczyniła się do zredefiniowania animistycznego światopoglądu, pisze, że dotąd animizm byt postrzegany jako uproszczona wersja religii bądź błędna epistemologia w dużym stopniu dlatego, że dotychczas definiowano go z perspektywy modernistycznej ${ }^{35}$. Podstawą tego światopoglądu były prace angielskiego badacza Edwarda Tylora, które w bardzo silny sposób oddziaływały na XX-wieczną antropologię Émila Durkheima, Claude'a Lévi-Straussa czy Stewarta Guthriego z jej dualistyczną koncepcją świata (opartą na rozróżnieniach między ciałem i dusza, tym, co ożywione i nieożywione, ludzkie i zwierzęce), którą aplikowano także społecznościom pierwotnym. Według badaczki wyjście poza ów modernistyczny paradygmat pozwala poddać krytyce dotychczasowe hierarchie oraz pojęcie ,ja” jako zamkniętej pojedynczej całości na rzecz równoczesnych i wzajemnych relacji, jakie tworzymy z otaczającym nas światem i jakie tworzą nas ${ }^{36}$. Wychodząc poza dualistyczną wizję rzeczywistości, Nurit Bird-David wprowadza pojęcie superosoby (zamiast nie-ludzkich bytów, gdyż terminologia ta punktem odniesienia nadal czyni człowieka), wskazując, że samo pojęcie osoby jest kategorią obejmującą zarówno osoby ludzkie, jak i zwierzęta czy choćby wiatr ${ }^{37}$.

Doskonałą filmową ewokacją lęku przed utratą modernistycznych roszczeń jest Szamanka (1996) Andrzeja Żuławskiego. Opowieść o fascynacji adepta antropologii prymitywną dziewczyną zestawiona z badaniami, jakie bohater prowadzi nad mumią szamana, miała w zamyśle dać wyraz kryzysowi cywilizacji. W rozmowie z twórcą Piotr Marecki i Piotr Kletowski próbują zaproponować bardziej afirmatywną wobec (neo)pogańszczyzny interpretację, wskazując na jej transgresyjny charakter. Kletowski chciałby widzieć film Żuławskiego obok takich dzieł, 
jak Ostatnie tango w Paryżu (Ultimo tango a Parigi, 1972) Bertolucciego czy Imperium zmystów (Ai no korîda, 1976) Ôshimy, dostrzega w nim opowieść o przekraczaniu granic prowadzącym ostatecznie bohatera do duchowego oświecenia ${ }^{38}$. Tymczasem Żuławski stoi na straży wyrazistych podziałów między kulturą i natura, męskim i kobiecym, cywilizowanym i prymitywnym, chrześcijańskim i pogańskim, intelektualnym i cielesnym, niepokojąc się upadkiem wartości w potransformacyjnym świecie. Okazuje się, że ani status naukowca, ani księdza (bohater próbuje schronić się w stanie kapłańskim) nie obronią Michała przed śmiercią i pożarciem przez tytułową szamankę. Pesymistyczna wizja świata sugeruje powrót przerażającej pogańszczyzny, który przyniesie dehumanizację i degradację człowieka do statusu mięsa, jakim - na kształt rzeźnych zwierząt pojawiających się w filmie stanie się bohater. Sławna scena końcowa z konsumowaniem mózgu bohatera staje się metaforą rozpadu dotychczasowego świata, po którym - jak przekonuje twórca - właściwie nic nie zostaje $e^{39}$.

Tymczasem nowo powstałe dzieła wykraczają poza ów modernistyczny paradygmat, burząc dotychczasowe hierarchie antropocentryczne, a także zrównując osobowy status istnień ludzkich i nie-ludzkich, jak dzieje się choćby we wspomnianej Wyspie Klimkiewicz czy w filmie Body/Ciało, gdzie tożsamość tę zyskują zmarli. Podstawą nowego animizmu jest jednak przede wszystkim relacyjność jako źródło upodmiotowienia otaczającego nas świata. Światopogląd ten rodzi się bowiem "z pomiędzy", z wzajemnych relacji między osobami (często różnych gatunków), nie "wewnatrz", za sprawa uduchowienia czy przejęcia przez duchy ${ }^{40}$. Dzięki wzajemnym interakcjom, stanowiącym podstawę naszego codziennego doświadczenia, następuje przekroczenie między człowiekiem a tym, co nie-ludzkie, oraz rozszerzenie pojęcia podmiotowości.

Manifestem tej relacji stał się Pokot Agnieszki Holland, w którym Janina Duszejko, inżynierka w wieku emerytalnym, walczy z arogancją prowincjonalnej społeczności wobec świata zwierząt. Choć należący do tej społeczności ksiądz Szelest zarzuca bohaterce, że wierzy w istnienie zwierzęcych dusz, to wydaje się jednak, że jej stosunek do nie-ludzkich osób opiera się raczej na codziennym doświadczeniu. Sebastian Smoliński, analizując Pokot pod kątem zawartej w nim antropocentrycznej wizji świata, wskazuje, że nazywanie przez bohaterkę jej psich podopiecznych „dziewczynkami” infantylizuje psy i sytuuje je w relacji podrzędności wobec opiekunki, która nie respektując ich odrębności, poddaje je antropomorfizacji ${ }^{41}$. Tymczasem z perspektywy animistycznej "dziewczynki” czy „córeczki” są wyrazem działań, na jakich opiera się relacja między Duszejko a sukami - sprawowanej nad nimi opieki czy zapewniania im pożywienia. To czyni je - jak działo się w społecznościach zbieraczo-łowieckich (a z taką jej współczesną odsłoną mamy do czynienia w filmie) - superosobami, które były nazywane przez człowieka właśnie za pomocą określeń pokrewieństwa ${ }^{42}$. Ludzie postrzegaja superosoby jako przyjaciół lub krewnych i często odnosza się do nich wedtug zasad pokrewieństwa ${ }^{43}$ - precyzuje Bird-David. Duszejko traktuje zresztą w podobny sposób otaczające ją przedmioty, które jak mówi, "garną się do niej same", a swój samochód nazywa „swoim dobrym przyjacielem” lub „kochaniutkim”, z którym było jej tak dobrze. Pozwala to zrozumieć perspektywę nowego animizmu, odsyłającą do współczesnych powszechnych doświadczeń, gdy personalizujemy komputer, którego używamy, rośliny, które pielęgnujemy, i samochody, którymi jeździmy, kształtując je 
poprzez tworzona z nimi relacje. Uczymy się tego, co one robia w relacji do tego, co my robimy, jak odpowiadaja na nasze działania, jak zachowuja się wobec nas, jak funkcjonuja (a nie jakie sa ich konstytutywne cechy) w konkretnej sytuacji4t.

Obarczanie przez bohaterkę zwierząt odpowiedzialnością za zbrodnie, których dokonuje, ma zatem sprawić, by pozostali członkowie społeczności doświadczyli ich działań i dzięki temu nadali im status osobowy, jak ma to miejsce u Indian, którzy sa przekonani, że byty naturalne posiadaja swój osobowy aspekt, gdyż doświadczaja przejawów intencjonalności owych bytów ${ }^{45}$. Sprawczość w Pokocie pochodzi zresztą nie tylko od zwierząt, lecz także od planet, a w innych filmach od środowiska (Śniegu już nigdy nie będzie) czy duchów zmarłych (Body/Ciało, Wyspa, Wieża. Jasny dzień). Takie oddziaływanie na bohaterów staje się warunkiem nadania innym istnieniom statusu podmiotowego. Mimo że Duszejko, inscenizując miejsca zbrodni, pomaga swoimi działaniami sprawstwu zwierząt, to jednak zwykła kość, która utknie w gardle Wielkiej Stopy, uruchomi lawinę zdarzeń: dziki stratują Wnętrzaka, zgniotek szkarłatny doprowadzi do śmierci prezesa, a sroka natchnie bohaterkę do podpalenia kościoła.

\section{Szaman(k)i}

Poszerzenie świata o byty o statusie osobowym zaowocowało potrzebą znalezienia przewodników, którzy potrafiliby rozpoznać tę nową rzeczywistość. Roli tej - jak przekonuje Pokot czy Wieża. Jasny dzień - nie potrafi sprostać ani religia judeochrześcijańska, ani jej kapłani. We wszystkich wspomnianych filmach występuje postać mediatora (częściej mediatorki) między światem ludzkim i nieludzkim. Janina Duszejko komunikuje się ze zwierzętami, Anna (Body/Ciało) i Baba Wanga (Baba Wanga) mediują z duchami zmarłych, Kaja (Wieża. Jasny dzień) porozumiewa się ze światem natury, podobnie jak Żenia, rosyjski masażysta-hipnotyzer-uzdrowiciel ze Śniegu już nigdy nie będzie. Małgorzata Szumowska mimo że w swoich filmach nawiązuje do kina Kieślowskiego, oddala się od zawartych w nim chrześcijańskich konotacji na rzecz spirytyzmu, któremu bliżej do reinkarnacji, szamanizmu, mediumiczności i XIX-wiecznej wiary w obecność duchów zmarłych.

Wspomniane postacie mają cechy szamanów i sprawują funkcje, jakie szamani niegdyś spełniali w swoich społecznościach. Według definicji Andrzeja Szyjewskiego zwykle sa to osoby, które potrafia kontaktować się z rzeczywistościq przekraczająca wymiar naoczności, ze światem dusz i bogów, zarówno w postaci podziemnej krainy zmartych i krwiożerczych demonów, jak i niebieskich sfer, oraz z duchami obecnymi w otoczeniu przyrodniczym $i$ z ukrytymi przed oczami zwykłych członków społecznościti. Odgrywają oni role wizjonerów, uzdrawiaczy, kapłanów, czarowników, proroków, wróżbitów, meteorologów, tropicieli zwierzyny oswojonej i łownej, umieją też przepowiadać przyszłość. Żenia z filmu Szumowskiej za sprawą hipnozy przenosi swoich „pacjentów” do równoległej, leśnej rzeczywistości, gdzie - jak możemy się domyślić - doświadczają zniesienia granicy między sobą a otaczającym ich światem. Jan Mikolášek w Szarlatanie leczy dzięki znajomości ziół. Jednak wiedza, którą posiadł, nie pochodzi z książek, ale została mu przekazana - jak w społecznościach pierwotnych - ustnie przez praktykującą ziołolecznictwo Mühlbacherovą. Natomiast Anna z Body/Ciało wykorzystuje w terapii ekstatyczny trans ${ }^{47}$. Jak pisze Szyjewski, współczesny, eklektyczny szamanizm 


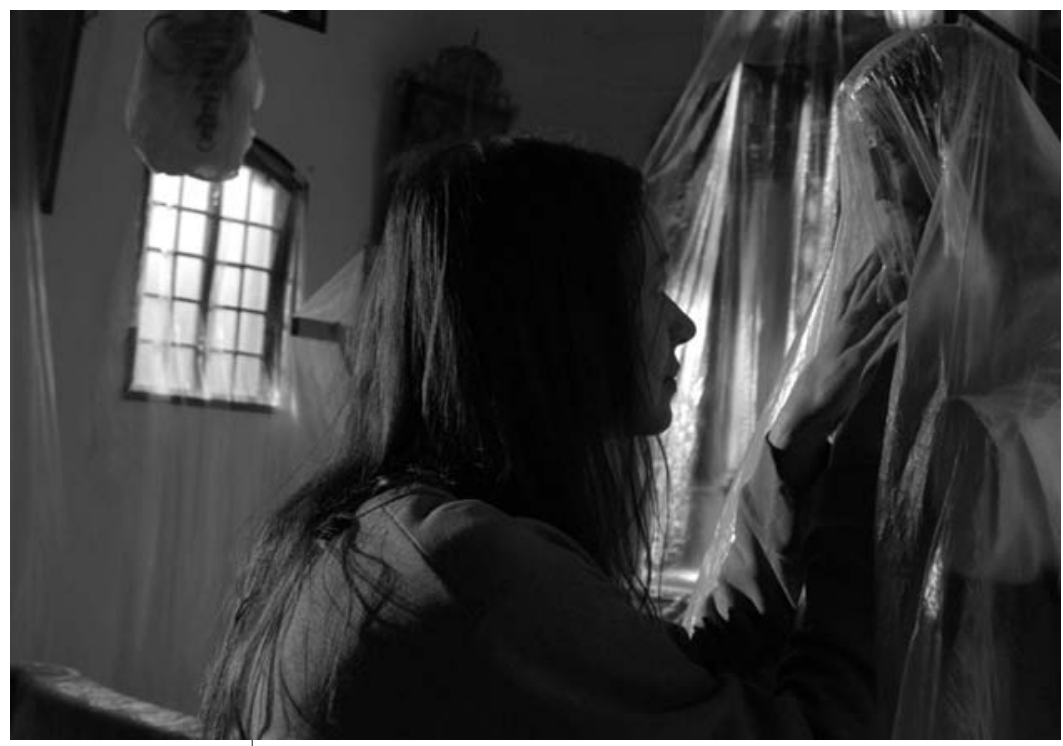

Wieża. Fasny dzień, reż. Jagoda Szelc (2017)

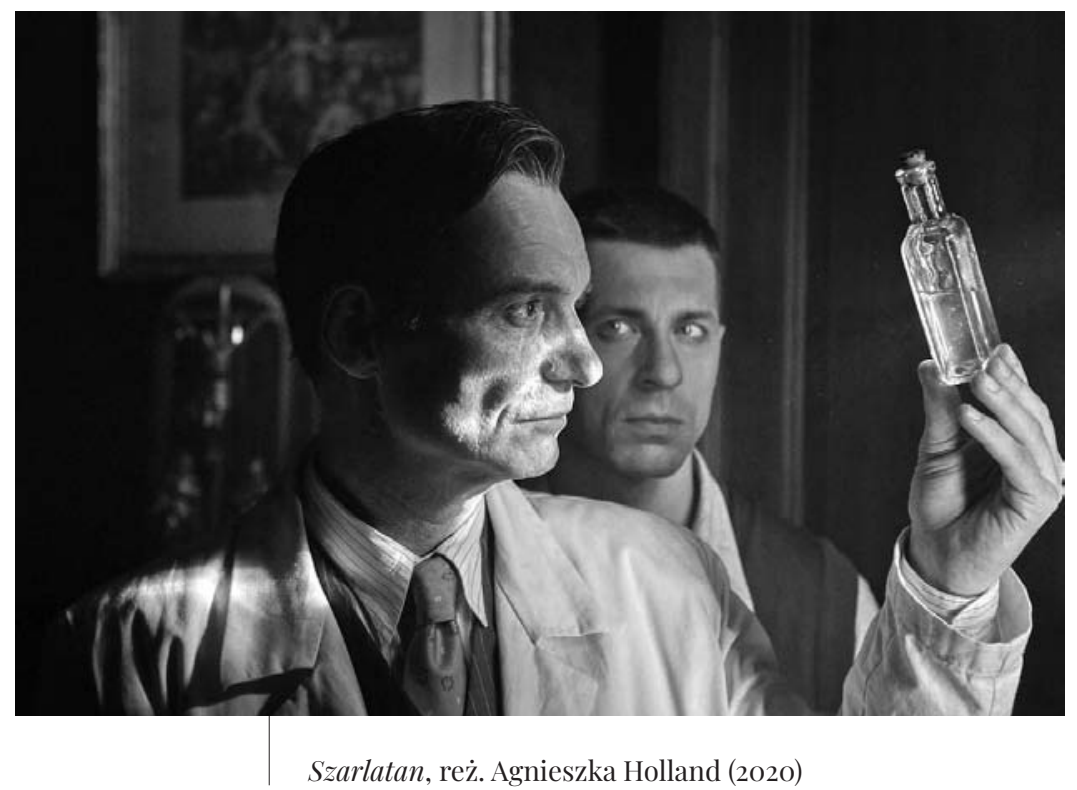


obejmuje elementy jogi, ćwiczenia oddechowe, wizualizacje, bębny. Bębnienie, niezależnie od pochodzenia instrumentu, ma powodować podróż do mitycznego świata ${ }^{48}$, a okrzyk „Ha” wyrzucać wszystkie blokujące emocje, jak gniew, lęk, wstyd, poczucie winy itp..$^{49}$ Warsztaty, w których uczestniczą pacjentki Anny, są wzorcowym odzwierciedleniem tych zachowań, włączając okrzyki „Ha” i bębnienie. W swego rodzaju taneczny trans podczas dorocznej zabawy grzybiarzy wchodzi również Duszejko, co przywiedzie ją do kolejnego morderstwa, a także Baba Wanga przepowiadająca przyszłość.

Rolą szamana było też zapewnienie zrównoważenia ekologicznego w gospodarowaniu zasobami naturalnymi, zwierzęcymi i roślinnymi $i^{50}$. W niewielkich społecznościach zbieraczo-łowieckich jego zadanie polegało na utrzymaniu równowagi między żywymi oraz duchami i przyroda, ponieważ relacje te są oparte na systemie wymiany. Natura, reprezentowana w umyśle szamana przez duchy, użycza ludziom mięsa zwierzat, by mogli się nim żywić. Natomiast dtug ze strony ludzi jest zwracany tak, że po śmierci ciała $i$ dusze ludzi sa przekazywane we władzę duchów $w^{51}$. Gdy system ten zostaje zachwiany na rzecz nadmiernej eksploatacji środowiska przez człowieka, pojawiają się wśród ludzi choroby czy wypadki śmiertelne mające ów bilans wyrównać. Duszejko przystaje na obecność myśliwych wtedy, gdy respektują kalendarz łowów, zwalczają kłusownictwo i nie polują na zwierzęta towarzyszące. Jednak w momencie, gdy łamią te zasady, zaczyna czuwać nad sprawiedliwą wymianą. Jest więc konsekwentna, chroniąc zwierzęta, a zabijając ludzi, ponieważ z perspektywy animistycznej pełni funkcję strażnika systemu wzajemności, przelewając jedno istnienie w drugie, oraz funkcję negocjatora między światem żywych i umarłych $^{52}$. Szamańskiej proweniencji jest także wcielenie się bohaterki w wilka za sprawą kostiumu, który przywdziewa, co odsyła do szamańskich praktyk metafizycznej identyfikacji z dzikimi zwierzętami ${ }^{53}$. We współczesnym neoszamanizmie obecne w świecie formy energii można wykorzystać także dzięki naśladownictwu tak zwanych zwierząt mocy: Trzeba się z nimi w ten czy inny sposób porozumieć, by wykorzystać ich siłę i zyskać zaświatowego "sprzymierzeńca”. Wówczas, podobnie jak w tradycyjnym szamanizmie, mówi się o pożarciu przez zwierzę, co symbolizować ma wymiar duchowego zjednoczenia. Temu celowi stuża różne techniki, m.in. zalecany przez Hernera taniec z naśladowaniem zachowania danego zwierzęcia lub z jakąs jego cząstka (amuletem $)^{54}$. Jednocześnie w słowiańskiej mitologii w przypadku młodych wojowników naśladowanie zwierzęcia przez narzucenie skóry drapieżnika miało przeksztatcać ich psychikę, zwalniając z norm ludzkich ${ }^{55}$.

Wszystkie te cechy odnoszą się do Duszejko, która stając się reprezentantką świata zwierząt, jednocześnie występuje w roli egzekutora jego praw. Zwykle animistyczna wizja świata łączy się z głębszą wrażliwością ekologiczną. Szyjewski wskazuje, że współczesny neoszamanizm cechuje świadomość ekologiczna w sensie głębokiej ekologii, wynikająca z holistycznego postrzegania świata ${ }^{56}$. Jest ona obecna naturalnie w Pokocie, lecz dotyczy także pozostałych filmów: Wieży. Jasnego dnia - odnoszącej się do relacji człowieka z Ziemią-Gają (bohaterka filmu nosi znaczące imię Kaja), Wyspy ${ }^{57}$ - sugerującej rozdźwięk między aktualnym modelem życia a animistyczną rzeczywistością wyspy czy Walsera - jednoznacznego oskarżenia nowoczesnej cywilizacji o zniszczenie środowiska naturalnego. Kathryn Rountree, badaczka współczesnych nurtów neopogańskich, zwraca uwagę, że nawet te, które mają charakter transnarodowy i eklektyczny, są bardzo często zaangażowane w fe- 


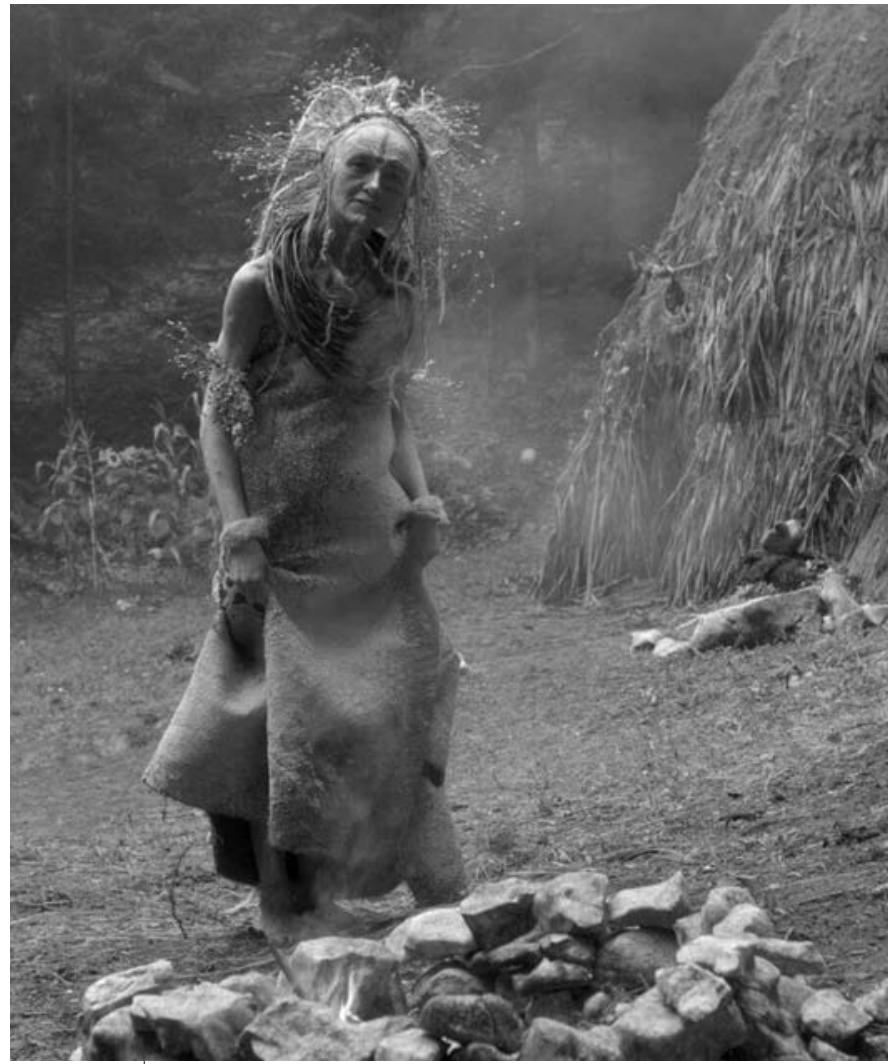

Walser, reż. Zbigniew Libera (2015)

minizm i wszelkiego rodzaju ruchy równościowe, a także politykę $i$ aktywizm na rzecz ochrony środowiska ${ }^{58}$. Ostatni z wymienionych filmów cechuje w tym zakresie największy pesymizm - przybycie kolejarza do społeczności plemiennej kończy się dla niej katastrofą i brakiem perspektyw na odrodzenie. W odróżnieniu od niego pozostałe obrazy - nawet takie jak apokaliptyczna Wieża. Jasny dzień - dają nadzieję na przezwyciężenie eksploatacyjnego, autorytatywnego stosunku do otaczającej nas rzeczywistości.

\section{Filmowy zwrot ontologiczny}

Doświadczenie szamana jest jednym ze źródeł informacji o świecie, a równocześnie drogą do ustalenia jego ontologii. Skoro szaman jest skuteczny w swoich działaniach, oznacza to, że nawet jeśli niektóre aspekty tego świata są niewidzialne, to stan ten nie zaprzecza ich istnieniu. Skuteczność w tych wszystkich praktycznych sytuacjach (leczenie, polowanie, zabijanie) może skłaniać (...) do potraktowania doświadczenia szamana jako wiarygodnego źródła wiedzy o sprawczych bytach zamieszkujących świat w ontologii animistycznej5. Innymi słowy ludzie żyja w różnych rzeczywistościach w sensie ontologicznym ${ }^{60}$, które jednak są uprawnione w zależności od ich doświadczenia. $Z$ tego rodzaju ontologiami opartymi na animistycznej wizji 
świata mamy do czynienia we wskazanych filmach. Zamiast więc rozstrzygać, czy Anna z Body/Ciało naprawdę rozmawia z duchami, czy też ma halucynacje, należy przystać na taką rzeczywistość, w której postawa ta jest racjonalnym i praktycznym sposobem $\dot{z} y c i a^{61}$, równie realnym jak picie porannej kawy. Społeczności, która się wokół niej gromadzi, rozmowa ze zmarłymi przynosi wymierne efekty, o czym przekonają się ostatecznie Olga i jej ojciec. Nawet oszustwo, do jakiego przyznaje się Olga, nie zachwieje pewnością mediumicznej terapeutki, która ostatecznie doprowadzi do zgody zwaśnionych stron i stworzenia więzi rodzinnej. Oboczność wspomnianych ontologii - zależnych od doświadczenia - wyraża także ostatnia scena: jednoczesnej obecności i nieobecności Anny w mieszkaniu ojca i córki. Podobny trop znajdziemy w filmie Śniegu już nigdy nie będzie, gdy hipnotyzer Żenia znika równie nieoczekiwanie, jak się pojawił, co każe się zastanowić nad jego statusem ontologicznym. Natomiast w Pokocie najpierw zostaje ustanowiona rzeczywistość, w której możliwa jest zemsta zwierząt, zaś w ostatniej scenie zatytułowanej „rzeczywistość urodzi się na nowo” twórczyni kreuje świat podlegający zasadom animistycznym, w którym przechodniość ontologiczna jest jak najbardziej oczywista - Duszejko i jej suki są w nim obecne, choć czasem niewidzialne.

Według Pawła Chyca obok doświadczenia szamanizmu ontologię animistyczną budują także dwa inne stany: sen i samotność, stanowiąc źródło wiedzy dla członków społeczności, którzy dzięki nim komunikują się z niewidzialnym sprawczym bytem $^{62}$. Przeżycie samotności jest udziałem niemal wszystkich bohaterów wskazanych filmów, natomiast śnienie i jego rola stanie się źródłem wiedzy Żeni, bohatera filmu Śniegu już nigdy nie będzie. Za sprawą hipnozy dopuszcza on swoich klientów do rzeczywistości, za jaką tęsknia, lecz jest dla nich niedostępna. Sam również pamięć o własnej przeszłości czerpie z rzeczywistości snu, skąd pochodzi i dokąd ostatecznie powróci. Świat wokół podobnie postrzega Kaja z Wieży. Jasnego dnia - bytując w rzeczywistości, w której swoje moce manifestuje natura (Kaja jest znawczynią ziół) i gdzie przebywają zmarli. Światy te nie są definiowane jako subiektywne zaburzenie bądź halucynacje, ale pewnego rodzaju poszerzona rzeczywistość, wobec której empiryczne, obiektywizujące spojrzenie, próbujące wyznaczyć jej jasne granice, podlega załamaniu.

Omawiane filmy, odpowiadając światopoglądowi reprezentowanemu przez peryferyjny nurt pogański, wskazują na konieczność sięgnięcia po inne formy postrzegania i określania otaczającej nas rzeczywistości, które pozwolą ponownie przemyśleć miejsce człowieka wśród nie-ludzkich i nie-ożywionych bytów oraz przyjrzeć się relacjom, jakie z nimi tworzy. Jak wskazuje Graham Harvey, współczesne nurty neopogańskie wykorzystuja animizm jako praktyczne odniesienie w próbach zwrócenia uwagi na przynależność człowieka do pozaludzkiej, wielogatunkowej wspólnoty. Tego rodzaju animizm jest relacyjny, ucieleśniony, zaangażowany ekologicznie i częściej "naturalistyczny" niż metafizyczny ${ }^{63}$. Jednocześnie filmy, które czerpią inspiracje z tego nurtu, prezentują zwykle świat w kryzysie, który jest utożsamiany z racjonalnością, zasadami patriarchalnymi, zagrożeniami środowiskowymi, antropocentryczną arogancją czy autorytaryzmem. Istotnie więc ów alternatywny model jawi się jako wspomniana „perspektywa ratunkowa”, możliwa forma ucieczki bądź pozytywnie waloryzowanego buntu. Nawet jeśli - jak u Małgorzaty Szumowskiej - 
postawy reprezentowane przez Annę (Body/Ciało) czy przez bohaterów Śniegu już nigdy nie będzie poddawane są próbie ironii, ich wartość nie zostaje zakwestionowana. Zawarty w przywołanych filmach optymizm płynący z możliwości upowszechnienia alternatywnego wzorca jest jednak bardzo ostrożny. Pojawia się raczej w formie obietnicy - tak jak w Pokocie - że „rzeczywistość urodzi się na nowo", niż przyjmuje kształt światów skończonych, opartych na nowych wartościach.

${ }^{1}$ K. Klimkiewicz, Następny film zrobię o młodej dziewczynie, https://pisf.pl/aktualnosci/katarzyna-klimkiewicz-nastepny-film-zrobie-o-mlodej-dziewczynie/\# (dostęp: 12.04.2021).

${ }^{2} \mathrm{~W}$ powieści J. I. Kraszewskiego Masław bohater zostaje jednoznacznie potępiony jako pyszny uzurpator, działający z niskich pobudek i skazany na klęskę. Zob. M. Janion, Niesamowita Słowiańszczyzna. Fantazmaty literatury, Wydawnictwo Literackie, Kraków 2006, s. 95, 106-107.

${ }^{3}$ A. Filipowicz, Zaktualizować przeszłość. Nowy animizm jako rodzima "perspektywa ratunko$w a "$, "Sensus Historiae" 2020, t. 38, nr 1, s. $183-184$.

${ }^{4}$ M. Janion, dz. cyt., s. 329.

${ }^{5}$ A. Filipowicz, dz. cyt., s. 183

${ }^{6}$ Inną propozycją poszukiwania w słowiańskiej - lecz nie pogańskiej - przeszłości wzorców godnych rewaloryzacji, które przeciwstawiłyby się nękającej Polaków niskiej samoocenie, opartej na resentymencie megalomanii, jest powrót do sarmatyzmu. Miałby on dostarczyć niezbędnego poczucia własnej wartości, stać się wehikułem tolerancji. Zob. E. M. Thompson, Sarmatyzm i postkolonializm. O naturze polskich resentymentów, „Dziennik Gazeta Prawna” 5.11.2007, https://wiadomosci.dziennik.pl/wydarzenia/artykuly/193060, sarmatyzm-i-postkolonializm.html (dostęp: 12.04.2021).

${ }^{7}$ A. Filipowicz, Stowiański "nowy animizm". Wokót badań terenowych polskiego romantyzmu, "Czas Kultury" 2020, nr 2, s. 120.

${ }^{8}$ M. Janion, dz. cyt., s. 65-66.

${ }^{9}$ A. Sapkowski, Piróg albo Nie ma złota w Szarych Górach, „Nowa Fantastyka” 1993, nr 5, https://sapkowskipl.wordpress.com/2017/03 /17/pirog-albo-nie-ma-zlota-w-szarych-gorach/ (dostęp: 21.03.2021).

10 Tamże.

${ }^{11}$ A. Gajda, Pogańska Słowiańszczyzna w literaturze polskiej, "Państwo i Społeczeństwo" 2008, nr 4, s. 168.
${ }^{12} \mathrm{~J}$. Lemann-Zajiček, Jan Rybkowski-baron polskiej kinematografii, w: Autorzy kina polskiego, red. G. Stachówna, B. Zmudziński, Wydawnictwo Uniwersytetu Jagiellońskiego, Kraków 2007, s. 27.

13 T. Lubelski, Historia kina polskiego. Twórcy, filmy, konteksty, Videograf II, Chorzów 2009, s. 353.

${ }^{14}$ M. Janion, dz. cyt., s. 94.

${ }^{15}$ Cytat pochodzi z filmu Lokis. Rękopis Profesora Wittembacha (1970) Janusza Majewskiego.

${ }^{16}$ A. Filipowicz, Stowiański "nowy animizm"... dz. cyt., s. 116.

${ }^{17}$ J. Majewski, Ostatni klaps. Pamiętnik moich filmów, Wydawnictwo Autorskie, Warszawa 2006, s. 96.

${ }^{18}$ P. Mérimée, Lokis i inne opowiadania, Wydawnictwo Śląsk, Katowice 1958, s. 11.

${ }^{19}$ A. Barcz, Realizm ekologiczny. Od ekokrytyki do zookrytyki w polskiej literaturze, Wydawnictwo Naukowe „Śląsk”, Katowice 2016, s. 60 .

${ }^{20}$ Tamże.

${ }^{21}$ A. Mickiewicz, Dziady wileńskie, Krakowska Spółka Wydawnicza, Kraków 1922, s. 49.

${ }^{22}$ A. Filipowicz, Zaktualizować przeszłość... dz. cyt., s. 188.

${ }^{23}$ P. Chyc, Wyobraźnia fantazmatyczna a animizm $w$ Amazonii. O ograniczeniach $w$ stosowaniu pojęcia fantazmat w badaniach antropologicznych, "Sensus Historiae" 2015, t. 21, nr 4, s. 53 .

${ }^{24}$ J. Kristeva, Potęga obrzydzenia. Esej o wstręcie, tłum. M. Falski, Wydawnictwo Uniwersytetu Jagiellońskiego, Kraków 2007, s. 8.

${ }^{25}$ Tamże, s. 9.

${ }^{26}$ Z. Przychodniak, Podwójna obcość. Początki polskiego stereotypu prześladowczego, w: Ulotność $i$ trwanie. Studia z tematologii $i$ historii literatury, red. E. Wiegandt, A. Czyżak, Z. Kopeć, Wydawnictwo „Poznańskie Studia Polonistyczne", Poznań 2003, s. 305.

${ }^{27}$ M. Janion, dz. cyt., s. 111.

${ }^{28}$ M. Maron, Romantyzm i kino. Idee i wyobrażenie romantyczne $w$ filmach polskich reżyserów 
z lat 1947-1990, Wydawnictwo Uniwersytetu Marii Curie-Skłodowskiej, Lublin 2019, s. 228.

${ }^{29}$ Zob. M. Janion, dz. cyt., s. 61-62.

30 Tamże, dz. cyt., s. 112.

${ }^{31}$ Piotr Szulkin. Życiopis. Z Piotrem Szulkinem rozmawiają Piotr Kletowski i Piotr Marecki, Korporacja Ha!art, Kraków 2012, s. 21.

32 Tamże.

33 Tamże, s. 24.

${ }^{34}$ E. Domańska, Nekros. Wprowadzenie do ontologii martwego ciała, Wydawnictwo Naukowe PWN, Warszawa 2017, s. 57.

${ }^{35}$ N. Bird-David, "Animism" Revisited: Personhood, Environment and Relational Epistemology, „Current Anthropology” 1999, nr 40, s. 67.

36 Tamże, s. 72.

37 Tamże, s. 71.

38 Żuławski. Przewodnik Krytyki Politycznej. Z Andrzejem Żuławskim rozmawiają Piotr Kletowski i Piotr Marecki, Wydawnictwo Krytyki Politycznej, Warszawa 2008, s. 425.

${ }^{39}$ Tamże, 425.

${ }^{40} \mathrm{G}$. Harvey, Introduction, w: The Handbook of Contemporary Animism, red. G. Harvey, Routledge, New York 2014, s. 3.

${ }^{41} \mathrm{~S}$. Smoliński, Między polityką zwierząt a zwierzęca polityka: nie-ludzka podmiotowość $w$ „Pokocie” Agnieszki Holland, „Pleograf. Kwartalnik Akademii Polskiego Filmu" 2018, nr 2, https://akademiapolskiegofilmu.pl/pl/historia-polskiego-filmu/pleograf/agnieszka-holland/12/miedzy-polityka-zwierzat-a-zwierzeca-polityka-nie-ludzka-podmiotowoscw-pokocie-agnieszki-holland/640 (dostęp: 11.04.2021).

${ }^{42}$ N. Bird-David, dz. cyt., s. 73.

43 Tamże, s. 78.

44 Tamże, s. 78.

${ }^{45}$ P. Chyc, Poczatek religii? Koncepcja animizmu w perspektywie antropologicznej, w: Człowiek, społeczeństwo, wiara. Studia interdyscyplinarne, red. B. Stawiarski, S. Rodak, Instytut Historyczny Uniwersytetu Wrocławskiego, Wrocław 2008, s. 121.

46 A. Szyjewski, Szamanizm, Wydawnictwo WAM, Kraków 2005, s. 8.

47 Tamże, s. 11.

48 Tamże, s. 216.

49 Tamże, s. 218.
50 Tamże, s. 16.

${ }^{51}$ Tamże, s. 30-31.

${ }^{52} \mathrm{O}$ systemie tym, w odniesieniu do społeczności amazońskich, pisze P. Chyc: Szamani lokalnych społeczności regularnie odwiedzaja Pana Zwierząt podczas halucynogennego transu. Negocjuja oni z nim liczbę zwierząt, która ma być wypuszczona do lasu, gdzie zostana upolowane przez członków ich lokalnych grup. Jednakże każde zwierze wypuszczone na polowanie musi być zrekompensowane przez dar z duszy zmarłego człowieka. Ta dusza zostanie przetransformowana w zwierze tego samego gatunku, co upolowane. Ludzie i nieludzie sa więc substytutami dla siebie samych $i$ ofiarowuja siebie nawzajem. Śmierć zwierzyny jest zawsze rekompensowana Panu Zwierzyny. Zob. P. Chyc, Poczatek religii?... dz. cyt., s. 122.

${ }^{53}$ A. Szyjewski, dz. cyt. s. 31.

54 Tamże, s. 220.

${ }^{55}$ A. Gieysztor, Mitologia Stowian, Wydawnictwo Uniwersytetu Warszawskiego, Warszawa 2006, s. 267.

${ }^{56}$ A. Szyjewski, dz. cyt., s. 222.

${ }_{57}$ M. Podsiadło, Ekokrytyczny trójgłos w kinie polskich reżyserek filmowych, „Pleograf. Kwartalnik Akademii Polskiego Filmu" 2019, nr 3, https://akademiapolskiegofilmu.pl/pl/historia-polskiego-filmu/pleograf/polskie-kinokobiet/18/ekokrytyczny-trojglos-w-kiniepolskich-rezyserek-filmowych/691 (dostęp: 11.04.2021).

${ }^{58}$ K. Rountree, Introduction: Context Is Everything: Plurality and Paradox in Contemporary European Paganisms, w: Contemporary Pagan and Native Faith Movements in Europe: Colonialist and Nationalist Impulses, red. K. Rountree, Berghahn, New York - Oxford 2015, s. 10.

${ }^{59}$ P. Chyc, Wyobraźnia fantazmatyczna... dz. cyt., s. 67.

${ }^{60}$ T. Rakowski, Etnografia i eksperymenty artystyczne. O powstawaniu nowych pól poznawczych we wspótczesnej antropologii, "Teksty Drugie" 2017, nr 1, s. 106.

${ }^{61}$ P. Chyc, Poczatek religii?... dz. cyt., s. 63.

${ }^{62}$ P. Chyc, Wyobraźnia fantazmatyczna... dz. cyt., s. 68.

${ }^{63}$ G. Harvey, dz. cyt., s. 2. 


\section{Magdalena Podsiadło-Kwiecień}

Absolwentka polonistyki i filmoznawstwa na Uniwersytecie Jagiellońskim; adiunkt w Katedrze Historii Filmu Polskiego Instytutu Sztuk Audiowizualnych Uniwersytetu Jagiellońskiego. Autorka książki Autobiografizm filmowy jako ślad podmiotowej egzystencji (2013) i współredaktorka tomów Kino polskie jako kino transnarodowe (2017) oraz Przygoda kina (2019). Publikowała w „Kwartalniku Filmowym”, „Kulturze i Historii" oraz tomach zbiorowych.

\section{Bibliografïa}

Barcz, A. (2016). Realizm ekologiczny. Od ekokrytyki do zookrytyki w polskiej literaturze. Katowice: Wydawnictwo Naukowe „Śląsk”.

Bird-David, N. (1999). "Animism" Revisited: Personhood, Environment, and Relational Epistemology. Current Anthropology, (40), ss. 67-79.

Chyc, P. (2008). Początek religii? Koncepcja animizmu w perspektywie antropologicznej. W: B. Stawiarski, S. Rodak (red.), Człowiek, społeczeństwo, wiara. Studia interdyscyplinarne (ss. 115-128). Wrocław: Instytut Historyczny Uniwersytetu Wroclawskiego.

Chyc, P. (2015). Wyobraźnia fantazmatyczna a animizm w Amazonii. O ograniczeniach w stosowaniu pojęcia fantazmat w badaniach antropologicznych. Sensus Historiae, 21 (4), ss. 53-72.

Domańska, E. (2017). Nekros. Wprowadzenie do ontologii martwego ciała. Warszawa: Wydawnictwo Naukowe PWN.

Filipowicz, A. (2020). Słowiański „nowy animizm”. Wokół badań terenowych polskiego romantyzmu. Czas Kultury, (2), ss. 115-121.

Filipowicz, A. (2020). Zaktualizować przeszłość. Nowy animizm jako rodzima „perspektywa ratunkowa”. Sensus Historiae, 38 (1), ss. 183-193.

Gajda, A. (2008). Pogańska Słowiańszczyzna w literaturze polskiej. Państwo i Społeczeństwo, (4), ss. 167-188.

Gieysztor, A. (2006). Mitologia Stowian. Warszawa: Wydawnictwo Uniwersytetu Warszawskiego.

Harvey, G. (2014). Introduction. W: G. Harvey (red.), The Handbook of Contemporary Animism (ss. 1-12). New York: Routledge.

Janion, M. (2006). Niesamowita Stowiańszczyzna. Fantazmaty literatury. Kraków: Wydawnictwo Literackie.

Klimkiewicz, K. (b. d.). Następny film zrobię o młodej dziewczynie. Pisf.pl. https://pisf.pl/aktualnosci/katarzyna-klimkiewicz-nastepny-film-zrobie-o-mlodej-dziewczynie/\#

Kristeva, J. (2007). Potęa obrzydzenia. Esej o zestręcie (thum. M. Falski). Kraków: Wydawnictwo Uniwersytetu Jagiellońskiego. (Publikacja oryginału: 1980).

Lemann-Zajiček, J. (2007). Jan Rybkowski - baron polskiej kinematografii. W: G. Stachówna, B. Zmudziński (red.), Autorzy kina polskiego (ss. 9-30). Kraków: Wydawnictwo Uniwersytetu Jagiellońskiego. 
Lubelski, T. (2009). Historia kina polskiego. Twórcy, filmy, konteksty. Chorzów: Videograf II.

Majewski, J. (2006). Ostatni klaps. Pamiętnik moich filmów. Warszawa: Wydawnictwo Autorskie.

Maron, M. (2019). Romantyzm i kino. Idee i wyobrażenie romantyczne w filmach polskich reżyserów z lat 1947-1990. Lublin: Wydawnictwo Uniwersytetu Marii Curie-Skłodowskiej.

Mérimée, P. (1958). Lokis i inne opoziadania. Katowice: Wydawnictwo Śląsk. (Publikacja oryginału: 1869$)$.

Mickiewicz, A. (1922). Dziady wileńskie. Kraków: Krakowska Spółka Wydawnicza.

Podsiadło, M. (2019). Ekokrytyczny trójgłos w kinie polskich reżyserek filmowych. Pleograf. Kwartalnik Akademii Polskiego Filmu, (3). https://akademiapolskiegofilmu.pl/pl/historia-polskiego-filmu/pleograf/polskie-kino-kobiet/18/ekokrytyczny-trojglos-w-kinie-polskich-rezyserek-filmowych/691

Przychodniak, Z. (2003). Podwójna obcość. Początki polskiego stereotypu prześladowczego. W: E. Wiegandt, A. Czyżak, Z. Kopeć (red.), Ulotność i trwanie. Studia z tematologii $i$ historii literatury (ss. 295-310). Poznań: Wydawnictwo „Poznańskie Studia Polonistyczne".

Rakowski, T. (2017). Etnografia i eksperymenty artystyczne. O powstawaniu nowych pól poznawczych we współczesnej antropologii. Teksty Drugie, (1), ss. 91-110.

Rountree, K. (2015). Introduction: Context Is Everything: Plurality and Paradox in Contemporary European Paganisms. W: K. Rountree (red.), Contemporary Pagan and Native Faith Movements in Europe: Colonialist and Nationalist Impulses (ss. 1-23). New York - Oxford: Berghahn.

Sapkowski, A. (1993). Piróg albo Nie ma złota w Szarych Górach. Nowa Fantastyka, (5). https://sapkowskipl.wordpress.com/2017/o3/17/pirog-albo-nie-ma-zlota-w-szarych-gorach/

Smoliński, S. (2018). Między polityką zwierząt a zwierzęcą polityką: nie-ludzka podmiotowość w „Pokocie” Agnieszki Holland. Pleograf. Kïartalnik Akademii Polskiego Filmu, (2). https://akademiapolskiegofilmu.pl/pl/historia-polskiego-filmu/pleograf/agnieszka-holland/12/miedzy-polityka-zwierzat-a-zwierzeca-polityka-nieludzka-podmiotowosc-w-pokocie-agnieszki-holland/640

Szulkin, P., Kletowski, P., Marecki, P. (2012). Piotr Szulkin. życiopis. Z Piotrem Szulkinem rozmawiają Piotr Kletowski i Piotr Marecki. Kraków: Korporacja Ha!art.

Szyjewski, A. (2005). Szamanizm. Kraków: Wydawnictwo WAM.

Thompson, E. M. (2007, 5 listopada). Sarmatyzm i postkolonializm. O naturze polskich resentymentów. Dziennik. Gazeta Prawna. https://wiadomosci.dziennik.pl/wydarzenia/artykuly/19306o,sarmatyzm-i-postkolonializm.html.

Żuławski, A., Kletowski, P., Marecki, P. (2008). ¿̇ułaðski. Przeðodnik Krytyki Politycznej. Z Andrzejem Żuławskim rozmawiają Piotr Kletowski i Piotr Marecki. Warszawa: Wydawnictwo Krytyki Politycznej. 
Keywords:

animism; paganism;

Polish cinema; abject

\author{
Abstract \\ Magdalena Podsiadło-Kwiecień \\ Between the Years of Yore and Younger Years - (Neo)Ani- \\ mistic and (Neo)Pagan Tropes in Polish Cinema \\ The perspective of new animism offers an approach to the
} subjectivity and the relation between nature and culture, the human and non-human, as well as the animate and the inanimate, that differs from the one founded on the JudeoChristian tradition. Marginal in Polish culture, this current can be found in film representations of paganism that nevertheless lend it the status of a repressed phenomenon or one tamed by the context of Christianity. The authors of contemporary Polish films that refer to this tradition look for an alternative to a world that is hierarchical, dualistic and based on an anthropocentric model. They connect with paganism though their egalitarian attitude towards animals (Agnieszka Holland's Spoor), respect for the agency of plants (Agnieszka Holland's Charlatan), belief in spirits beyond the Christian context (Małgorzata Szumowska's Never Gonna Snow Again and Body), awareness of the natural environment (Katarzyna Klimkiewicz and Dominga Sotomayor Castillos's La Isla) or reference to tribal cultures (Zbigniew Libera's Walser). At the same time, these works re-evaluate said tradition, treating it as a "rescue perspective" in the face of the current civilizational crisis. 